\title{
MOLECULAR STUDY OF Aeromonas hydrophila ISOLATED FROM STOOL SAMPLES IN NAJAF (IRAQ)
}

\author{
AL-FATLAWY H.N.K. ${ }^{*}$ AND AL-AMMAR M.H. \\ Department of Biology, College of Sciences, Kufa University, Najaf, Iraq. \\ *Corresponding Author: Email- hawraank1@yahoo.com
}

\section{Received: February 05, 2013; Accepted: February 21, 2013}

\begin{abstract}
The present study included the detection of $A$. hydrophila in some clinical cases in the governorate of AL-Najaf, during the period from October 2011 to March 2012.The samples was collected from stool samples for A. hydrophila isolates. The PCR method of gene (16S rRNA) was the best methods for diagnosis, which has led to isolate and diagnosis of (23) isolate of $A$. hydrophila from stool samples. The PCR technique was used for detection of some genes in $A$. hydrophila like heamolysin (hyl) and aerolysin (aerA) genes which were responsible for pathogenicity of bacteria. The (hyl)and (aerA) genes presented in $(80 \%, 72 \%)$ respectively for the clinical isolates.

Keywords- Aerolysin and heamolysin genes, 16SrRNA, Aeromonas hydrophila, PCR
\end{abstract}

Citation: Al-Fatlawy H.N.K. and Al-Ammar M.H. (2013) Molecular Study of Aeromonas hydrophila Isolated from Stool Samples in Najaf (Iraq). International Journal of Microbiology Research, ISSN: 0975-5276 \& E-ISSN: 0975-9174, Volume 5, Issue 1, pp.-363-366. DOI : 10.9735/09755276.5.1.363-366.

Copyright: Copyright@2013 Al-Fatlawy H.N.K. and Al-Ammar M.H. This is an open-access article distributed under the terms of the Creative Commons Attribution License, which permits unrestricted use, distribution and reproduction in any medium, provided the original author and source are credited.

\section{Introduction}

Aeromonas hydrophila is one species of the genus Aeromonas that received increasing attention as opportunistic pathogens because of its association with human diseases and aquatic and terrestrial animals infections [1]. A. hydrophila is associated with both diarrheal and extraintestinal infection in human disease especially dangerous for children and persons with impaired immune system. The symptoms of the pathological features associated with infection caused by $A$. hydrophila refer to local enema, tissue necrosis, sepsis and mortality [2], resulting in the occurrence of disease entities such as gastroenteritis, wound infections, septicaemia, meningitis, peritonitis, endocarditis, osteomyelitis, etc [3]. This bacterium is linked to two types of gastroenteritis, the first type is a disease similar to cholera which causes rice- watery diarrhea and the other type of disease is dysenteric gastroenteritis that causes loose stools filled with blood and mucus. Dysenteric gastroenteritis is the most severe out of the two types [4].

The pathogenicity of $A$. hydrophila infection is complex and multifactoral [5], and it's attributed to a multiple virulence factors, including cell structural : lipopolysacchariede (LPS), outer membrane proteins (OMPs), pili and flagella, type III secretion system(T3SS) acts as adhesion structures and extracellular factors such as exotoxin, aerolysins, heamolysins, $\beta$-lactamase, enterotoxin and sidrophore that seem to play an important role in pathogenesis [2]

The PCR methods, have been developed for routine identification of the species of Aeromonas' most frequently involved in human disease [6] and to genetically detect putative virulence genes [7]. Molecular studies on Aeromonas species have received a little atten- tion in Iraq. The present study is carried out to achieve the following objectives

1. Isolation of $A$. hydrophila from diarrheal samples and identification by PCR technique, which used specific primer (16S rRNA) diagnostic gene.

2. Identification aerolysin and heamolysin genes in clinical isolates.

\section{Material and Methods}

Samples Collection- A total of 110 of diarrheal samples were obtained from patients who attended to Hospitals in AL Najaf governorate during the period from October 2011 to the March 2012.

\section{Identification of $A$. hydrophila}

- Microscopic Properties- Microscopic properties: Gram's stain was used to examine the isolated bacteria for studying the microscopic properties [8].

- Cultural Characteristics- Morphological colonies characteristics were recorded on the specific media for primary identification of $A$. hydrophila

- Biochemical Tests- Oxidase, catalase, Simmone Citrate, and Indole tests all these tests positive [9].

\section{API 20 E System}

API20E system was carried out according to the procedure of Biomerix company, France.

\section{Molecular Identification}

16S rRNA gene for confirmation the identification of $A$. hydrophila. 
PCR Assay:- The wizard genomic DNA purification kit is designed for isolation of DNA from G- bacteria. Gel electrophoresis was used for detection of DNA by UV transilluminator [10]. The PCR assay was performed to detect the (16S rRNA) gene for confirmation the identification of $A$. hydrophila and to detect the virulence factors genes, shown in [Table-1]. These primers synthesized by Alpha DNA company, Canada [11,12].

Table 1- Sequence and Concentration of Forward and Reverse Primers.

\begin{tabular}{|llcc|}
\hline Primer type & Primer sequence & \multicolumn{3}{c}{$\begin{array}{c}\text { Concentration Product } \\
\text { In picomoles }\end{array}$} & size \\
\hline 16Sr RNA - F & 5-CCAGCAGCCGCGGTAATACG-3 & 86900 & \multirow{2}{*}{$300 \mathrm{bp}$} \\
16Sr RNA - R 5-TACCAGGGTATCTAATCC-3 & 128177 & \\
aerA-F & 5'-AGCGGCAGAGCCCGTCTATCCA-3' & 92012 & \multirow{2}{*}{$416 \mathrm{bp}$} \\
aerA-R & 5'-AGTTGGTGGCGTGTCGTAGCG -3' & 75793 & \\
hyl -F & 5'-GGCCCGTGGCCCGAAGATGCAGG-3' & 73167 & \multirow{2}{*}{$597 \mathrm{bp}$} \\
hyl -R & 5- CAGTCCCACCCACTTC-3' & 94775 & \\
\hline
\end{tabular}

Concentration of DNA was determined spectrophotometrically by measuring its optical density at $260 \mathrm{~nm}$ (Extinction coefficient of dsDNA is $50 \mu \mathrm{g} / \mathrm{ml}$ at $260 \mathrm{~nm}$ ) the purity of DNA solution is indicated by ratio of OD260/OD280 which is in the range of $1.8 \pm 0.2$ for pure DNA [13]. PCR program that apply in the thermocyler illustrate in [Table-2]. The PCR products and the ladder marker are resolved by electrophoresis on $1.2 \%$ agarose gel $[11,12]$.

Table 2- PCR program that apply in the thermocyler.

\begin{tabular}{|c|c|c|c|c|c|}
\hline Gene & $\begin{array}{c}\text { Initial } \\
\text { denaturation }\end{array}$ & Denaturation & $\begin{array}{c}\text { Cycles } \\
\text { Annealing }\end{array}$ & Elongation & $\begin{array}{c}\text { Final } \\
\text { elongation }\end{array}$ \\
\hline $16 \mathrm{~S} r \mathrm{RNA}$ & $94^{\circ} \mathrm{C}$ for $3 \mathrm{~min}$ & $\begin{array}{l}94^{\circ} \mathrm{C} \text { for } 30 \\
\text { sec. }\end{array}$ & $\begin{array}{c}30 \text { cycles } \\
52^{\circ} \mathrm{C} \text { for } 30 \\
\text { sec. }\end{array}$ & $\begin{array}{l}72^{\circ} \mathrm{C} \text { for } 30 \\
\text { sec. }\end{array}$ & $\begin{array}{c}72^{\circ} \mathrm{C} \text { for } 10 \\
\min \end{array}$ \\
\hline $\begin{array}{l}\text { aerA } \\
\text { hyl }\end{array}$ & $95^{\circ} \mathrm{C}$ for $5 \mathrm{~min}$ & $\begin{array}{c}95^{\circ} \mathrm{C} \text { for } 30 \\
\text { min }\end{array}$ & $\begin{array}{c}30 \text { cycle } \\
55^{\circ} \mathrm{C} \text { for } 1 \\
\text { min }\end{array}$ & $\begin{array}{c}72^{\circ} \mathrm{C} \text { for } 1 \\
\min \end{array}$ & $\begin{array}{c}72^{\circ} \mathrm{C} \text { for } 7 \\
\min \end{array}$ \\
\hline
\end{tabular}

\section{Results}

\section{Isolation and Identification of $A$. hydrophila}

A total 110 samples were collected from patients suffering from diarrheal infection. The colonies of $A$. hydrophila are yellow shin color on TCBS agar [Fig-1] with diameter ranged from 2-3 mm. In addition to those colonies appeared as pale like shaped on the MacConkey agar indicated that $A$. hydrophila is unable to ferment lactose sugar. On blood agar $A$. hydrophila produces smooth, convex, rounded and $\beta$-hemolytic colonies and pale white to grey color, as show in [Fig-2].

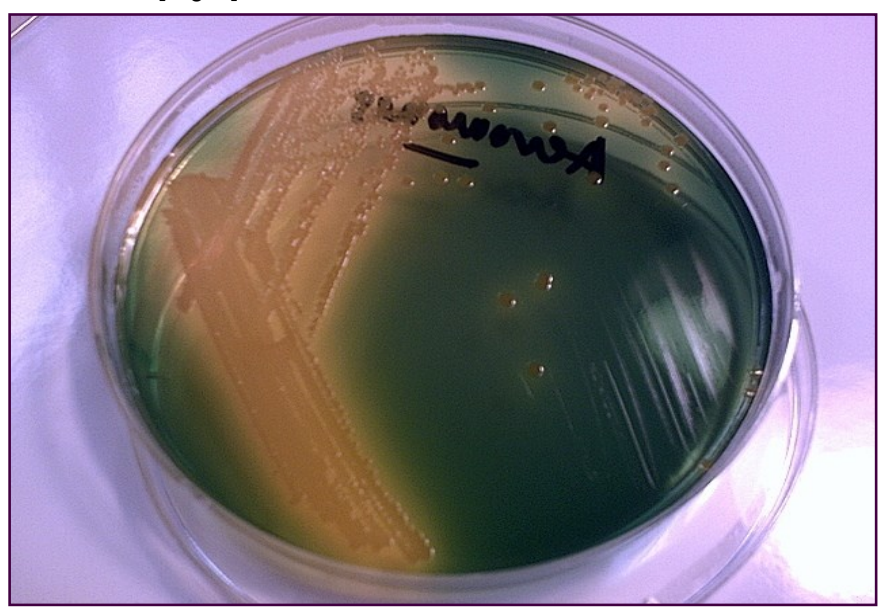

Fig. 1- A. hydrophila on Culture Media such as TCBS agar

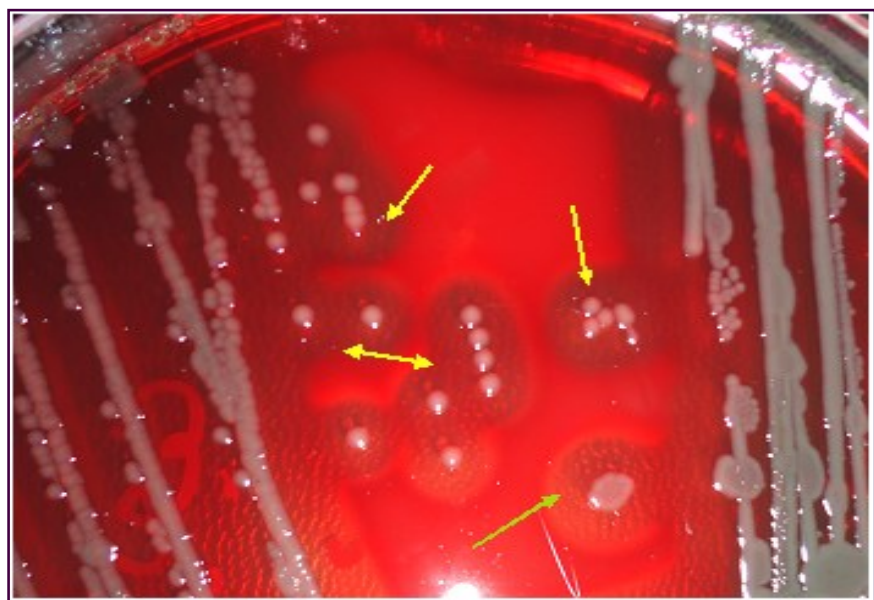

Fig. 2- A. hydrophila on Culture Media such as Blood agar

The results of biochemical tests indicated that 44 isolates belong to A. hydrophila, all isolates are positive result for oxidase test. $A$. hydrophila isolates are characterized by their ability to ferment glucose with gas formed on kligler iron agar (Alk/Acid), it produces (Alkaline) red color top and bottom (acidic) yellow color with gas formed but not H2S; it gives a positive result to, catalase, voguesProskauer, Indole, simmone citrate tests. A. hydrophila isolates gives negative result to string test, which is differentional test between A. hydrophila and $V$. cholera.

API 20E system is used to confirm identification of $A$. hydrophila included in this study. The results demonstrate that 26 clinical isolates are positive in identification by API 20E, Using the analytical profile index of this system the identification percentage is (id $\%=$ 97.8), and the rest strains give negative result.

\section{Molecular Identification of $A$. hydrophila by PCR Technique Detection of $16 \mathrm{Sr}$ RNA Gene of $A$. hydrophila.}

PCR technique has been used to amplify genes of $16 \mathrm{Sr}$ RNA gene from genomic DNA of all $A$. hydrophila isolates. DNA is extracted from all isolates. The results of isolates diagnosis using the PCR technique for 16SrRNA detection clarify that 23 isolates of $A$. hydrophila, producers carrying $16 S \mathrm{~S}$ RNA gene that is characteristic of $A$. hydrophila, as shown in [Fig-3].

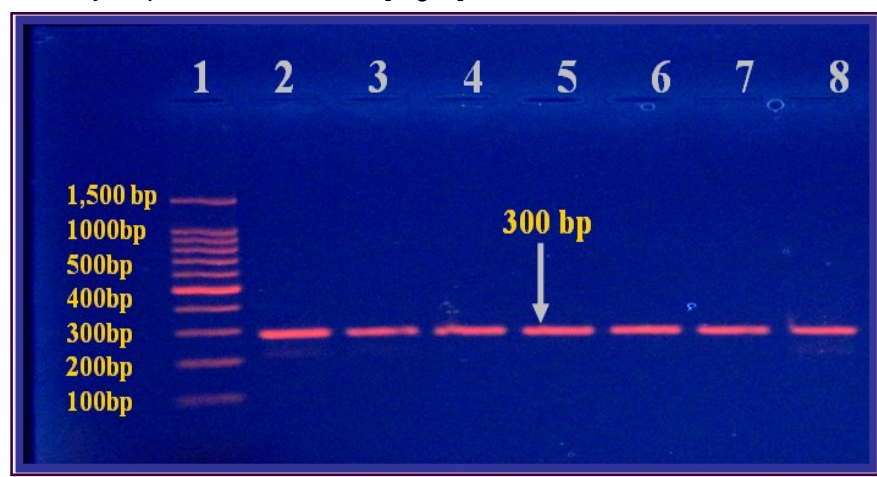

Fig. 3- Agarose Gel Electrophoresis 1.2\% of PCR Amplified of $16 \mathrm{~S}$ rRNA Gene 300 bp of $A$. hydrophila Isolates for 55 min at 100 volt. Lane 1 DNA marker (100bp ladder).

Lane 2,3,4,5,6,7,8 Amplify of $16 \mathrm{Sr}$ RNA gene in clinical isolates.

\section{Detection of Heamolysin Gene (hyl)}

PCR technique has been used to amplify heamolysin gene (hyl) from genomic DNA of all $A$. hydrophila isolates. Isolates with specif- 
ic primer, which responsible for heamolysin toxin, as shown in [Fig4]. Most of clinical isolates contain (80\%) of (hyl) gene of $A$. hydrophila.

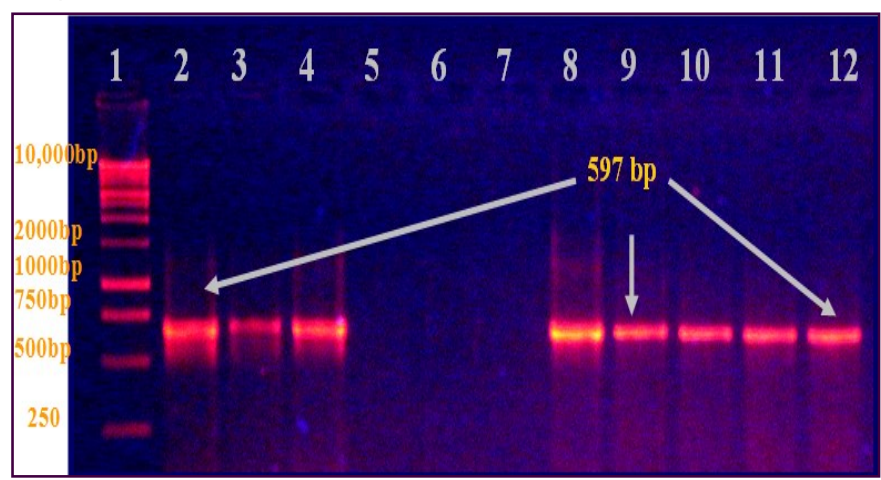

Fig. 4- Agarose Gel Electrophoresis 1.2\% of PCR Amplified of (hyl) gene $597 \mathrm{bp}$ of $A$. hydrophila isolates for $55 \mathrm{~min}$ at 100 Volt.

Lane 1 Marker (1 kb DNA ladder)

Lane 2,3,4,8,9,10,11 positive result for clinical isolates of $A$. hydrophila while 5,6,7 were negative result.

\section{Detection of Aerolysin Gene (aerA)}

Detection of Aerolysin gene (aerA) by PCR technique is presented in [Fig-5]. Clinical isolates of $A$. hydrophila possess $72 \%$ of this gene. Specific primers of aerA gene with genomic DNA of $A$. hydrophila isolates were used in this study

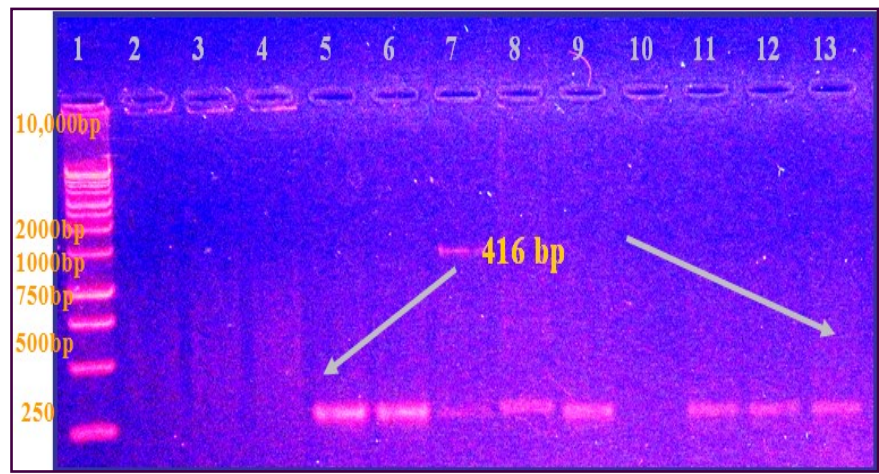

Fig. 5- Agarose Gel Electrophoresis $1.2 \%$ of PCR Amplify of (aerA) gene of $A$. hydrophila isolates for 55 min at 100 Volt.

Lane 1 Marker (1 kb DNA ladder)

Lane $5,6,7,8,9,11,12,13$ were positive result isolates of $A$. hydrophila while 2,3,4 and 10 were negative result.

\section{Discussion}

\section{Isolation and Bacteriological Diagnosis}

Identification of $A$. hydrophila depends on the colonial morphology, biochemical tests, Api20E system and molecular identification. The colonies of $A$. hydrophila are yellow shin /green color on TCBS agar due to sucrose ferment, with diameter ranged from 2-3 mm,these typical characteristics being described by referential studies [14]. In addition, those colonies appear as pale like shaped that indicated A. hydrophila is unable to ferment lactose sugar on the the MacConkey agar. A. hydrophila produces smooth, convex, rounded and $\beta$-hemolytic colonies when grow on the blood agar. These results are agree with $[15,16]$. A. hydrophilla consists of straight, coccobacillary to bacillary gram-negative bacteria with rounded ends, it occurs singly, in pairs, and rarely as short chains. Motile strains produce a single polar flagellum, though peritrichous or lateral, fla- gella [17]. The biochemical tests of $A$. hydrophila involved its ability to ferment glucose produces acid and gas, it ferments many sugars such as galactose, and, sucrose, but non-fermented arabinose and lactose,. It was able to grow on kligler iron agar and positive for catalase, Vogus-Proskaur reaction, and oxidase test but does not urease and $\mathrm{H} 2 \mathrm{~S}$ produced API2OE system is used to confirm identification of $A$. hydrophila [1]. The findings demonstrate that 59 clinical isolates are positive results in $\mathrm{API} 20 \mathrm{E}$, these results agree with $[18,19]$.

Table 3- Virulence factors genes of A. hydrophila in present study.

\begin{tabular}{lcccc} 
No. of isolates & \multicolumn{2}{c}{ Virulence factors genes } \\
(hyl) gene & Gene (aerA) & Both genes \\
\hline A.H 1 S & + & - & - \\
A.H 2 S & + & - & - \\
A.H3 S & + & - & - \\
A.H 4 S & - & + & - \\
A.H 5 S & - & + & - \\
A.H6 S & - & + & - \\
A.H7 S & + & + & + \\
A.H 8 S & + & + & + \\
A.H 9 S & + & - & - \\
A.H 10S & + & + & + \\
A.H 11S & + & + & + \\
A.H 12 S & + & - & + \\
A.H13 S & - & + & + \\
A.H14 S & + & + & + \\
A.H15 S & + & + & + \\
A.H16 S & + & + & + \\
A.H17 S & + & + & + \\
A.H18 S & + & + & + \\
A.H19 S & + & + & + \\
A.H20 S & - & + & + \\
A.H21 S & + & + & + \\
A.H22 S & + & + & + \\
A.H23 S & + & + & + \\
A.H.: A. & + & + & + \\
\hline
\end{tabular}

A.H.: A. hydrophila isolate, (hyl):heamolysin gene, (aerA): aerolysin gene, $S$ : Stool sample

\section{Molecular Identification of $A$. hydrophila by PCR Technique}

PCR technique has been used to amplify 16SrRNA gene from genomic DNA of all $A$. hydrophila. Results of the present study demonstrate significant differences between the methods used and PCR in the diagnosis for A. hydrophila isolates. Where the method of PCR was more sensitive compared to other methods, whereas it shown that 23 isolate were diagnostic as belong to $A$. hydrophila isolates, depending on the diagnostic gene $16 S$ rRNA, that selected specific primer to this gene according to [12]. Most isolates of $A$. hydrophila isolate gave a positive result to detected for (16SrRNA) gene $[7,20]$. who noted that the ribosomal mainly $16 S$ r RNA gene has proven to be a stable and specific molecular marker for the identification of $A$. hydrophila bacteria. The results agree with $[12,21]$ which refer that 16 rRNA gene was specific marker in all strain of $A$. hydrophila.

\section{Detection of Heamolysin gene (hyl) and Aerolysin gene (aerA)}

PCR is used to amplify a precise fragment of DNA from a complex mixture of starting material usually template genomic DNA. A number of reports are available for PCR amplification of conserved aerolysin gene and heamolysin gene of $A$. hydrophila [22]. Other virulence genes of $A$. hydrophila have also been detected by PCR [7].

The present study is conducted by PCR assays to detect the presence of specific virulence traits or the genes encoding these traits. The results of the present study show that most of $A$. hydrophila 
isolates from clinical samples gave a positive results to detection for (hyl A) gene by using the PCR technique, whereas these results show that clinical isolates of $A$. hydrophila are $80 \%$ to $($ hyl $A)$ gene while Aerolysin gene (aerA) were $72 \%$ by using PCR technique as shown [Fig-4], [Fig-5], and through statistical analysis was not observed any signification difference at level $p \leq 0.05$ (ANOVA) in all results between clinical isolates in the present study.

Whereas, (hyl) gene is observed as responsible for disease occurrence especially diarrhea, which is confirmed by some studies that some bacteria cause diarrhea by production of enterotoxins or by invasion of the gastrointestinal epithelium [2].

Aerolysin is a hemolytic toxin protein secreted by Aeromonas hydrophila. It is known that pathogenic isolates of $A$. hydrophila secrete aerolysin toxin that causes the lysis of the RBCs [23]. The results of this study agree with several studies $[11,22,24]$.

\section{Conclusions}

The following conclusions are extracted from the present study :1The molecular techniques is necessary for detection of pathogenic bacteria of clinical sources. 2- The molecular study provides definite identification of virulence factors such as aerolysin (aerA) and heamolysin (hyl).

\section{Acknowledgement}

Praise to the mighty "Allah" (SWT) who gave me health, strength, and facilitated the ways for me to accomplish this work. It is a pleasure to express my deep appreciation to my supervisorAssistant Professor Dr.Mahdi.H.M.AL-Ammar for the scientific guidance and support. I would like to thank all members of Biology Department and The Deanery of College of Sciences-Kufa University for their kind cooperation. My thanks to the staff members of Bacteriology laboratories in Al-Sadder Medical city and Al-Zahraa Educational Hospital in Najaf for facilitating the collection of specimens. I am very grateful to Dr. Hazim A.N. AL-Hadrawy, in College of Sciences, University of Kufa, for his continuous encouragement and extensive help during working.

\section{References}

[1] Naharro G., Riano J., de Castro L., Alvarez S., Luengo J.M. (2009) Aeromonas: Molecular Detection of Foodborne Pathogens, CRC Press. North Ryde, 273-289.

[2] Janda J.M. and Abbott S.L. (2010) Clinical Microbiology Reviews, 23, 35-73.

[3] Vally H., Whittle A., Cameron S., Dowse G.K., Watson T. (2004) Clin. Infect. Dis., 38, 1084-1089.

[4] Galindo C.L., Chopra A.K. (2007) Food Microbiology Fundamentals and Frontiers, ASM Press, Washington, 381-401.

[5] Chopra A.K., Xu X.J., Ribardo D., Gonzalez M., Kuhl K., Peterson J.W. and Houston C.W. (2000) Infect. Immun. 68, 28082818.

[6] Sen K. (2005) Canadian Journal of Microbiology, 51, 957-966.

[7] Singh V., Chaudhary D.K., Mani I. (2012) International Journal of Applied Biology and Pharmaceutical Technology, 3(1), 253260.

[8] Jawetz E., Melnick J.I. and Adelberg E.A. (2007) Medical Microbiology, 24th ed., Appleton and Lange, USA.

[9] MaccFadin J.K. (2000) Biochemical Test for Identification of Medical Bacteria, 3rd ed., Awolter Klumer Company, Philadel- phia Baltimor, New York.

[10]Sambrook J. and Russell R.W. (2001) Molecular Cloning: A Laboratory Manual, 3rd ed., Cold Spring Harbor Laboratory Press, N.Y.

[11]Yogananth N., Bhakyaraj R., Chantchuru A., Anbalagan T., Mullai Nila K. (2009) Global J. Biotechnol. Biochem., 4, 51-53.

[12]Jun J.W., Kim J.H., Gomez D.K., Choresca Jr C.H., Han J.E., Shin S.P. and Park S.C. (2010) African Journal of Microbiology Research, 4(9), 849-855.

[13]Stephenson F.H. (2003) Calculations in Molecular Biology and Biotechnology, Academic Press, California, USA.

[14]Abbott S.L., Cheung W.K. and Janda J.M. (2003) J. Clin. Microbiol., 41, 2348-23.

[15]Altwegg M. and Geiss H.K. (1989) CRC Crit. Rev. Microbiol., 16, 253-286

[16]Jayavignesh V., Sendesh Kannan K. and Bhat A.D. (2011) Arch. Appl. Sci. Res., 3(3), 85-93.

[17]Nordmann P. and Poirel L. (2002) Clinical Microbiology and Infection, 8, 321-331.

[18]Al-Taee R.K.I. (2002) Study of Some Virulence Factors of the Aeromonas hydrophila Bacteria Isolated from Clinical Source, M.Sc. Thesis, College of Science, University of Baghdad.

[19]Ali H.S.A. (2008) Studying the Crude Growth Extract Effect of Aeromonas hydrophila on Normal and Cancer Cell Lines, M.Sc. Thesis, College of Science, University of Kufa.

[20]Dorsch M. (1994) J. Appl. Bacteriol., 77, 722-726.

[21]Lane D.J., Stackebrandt E., Goodfellow M. (1991) Nucleic Acid Techniques in Bacterial Systematics, John Wiley \& Sons, New York, 115-175.

[22]Wang G., Clifford C.G., Liu C., Pucknell C., Munro C.K., Kruk T.M., Caldeira R., Woodward D.L. and Rodgers F.G. (2003) J. Clin. Microbiol., 41, 1048-1054.

[23]Singh V., Rathore G., Kapoor D., Mishra B.N., Lakra W.S. (2008) Indian J. Microbiol., 48, 453-458.

[24]Singh V., Rathore G., Kumar G., Swaminathan T.R., Sood N., Kapoor D. and Mishra B.N. (2007) Indian Vet. J., 84, 900-902. 